\title{
New Findings on the Underlying Neural Mechanism of Emotion Induced by Frightening Music
}

$\mathbf{I}_{\mathrm{n}}$ of Nuclear Medicine, Zhang et al. reported their novel finding that monoamine receptor changes can be triggered rapidly by frightening music (1). Using a PET receptor imaging approach, they investigated monoamine receptor changes induced by frightening music in healthy volunteers. Monoamine receptor antagonist ${ }^{11} \mathrm{C}-\mathrm{N}$-methyl-spiperone ( $\left.{ }^{11} \mathrm{C}-\mathrm{NMSP}\right)$ decreased in the limbic and paralimbic regions but increased in the cerebral cortex. Their results provided new and important insights into the underlying mechanism, on the synaptic level, for the correlation between emotion and frightening music.

\section{See page 1573}

Music has the ability to spark memories and evoke powerful emotions. The past decade has seen an exponential increase in studies of music and emotion. So far, most studies investigating the psychologic and neural basis for the impact of music on our emotions have focused on perception, induction, and recognition of basic emotions, such as happiness and sadness (2). Although changes in certain physiologic processes have been characterized in response to music, neural correlates of emotional responses to music have not been well studied. Contributing to the difficulty of studying emotions and music in a scientific context is that emotional responses to

Received Aug. 1, 2012; revision accepted Aug. 3, 2012.

Published online Sep. 6, 2012.

COPYRIGHT @ 2012 by the Society of Nuclear

Medicine and Molecular Imaging, Inc.

DOI: 10.2967/jnumed.112.109447 music tend to be idiosyncratic and heterogeneous and depend on a variety of complex and difficult-to-control individual sociocultural, historical, educational, and contextual variables.

Although people often disagree on what music they like, there is always agreement that frightening music tends to be scary (3). Frightening music is effective in inducing fear, which can rapidly arouse emotions in listeners that mimic those from actual life-threatening experiences. Those violent feelings of fear can arouse deeply memorable impressions and even create psychologic trauma, possibly contributing to anxiety disorders. In scary movies, music and sound effects are widely used to enhance the feeling of fear and anxiety. Although our emotional responses to music may be conditioned by memory, the ability to recognize the emotional character of musical excerpts is remarkably consistent across listeners, independent of music education, as reported by Bigand et al. (4). Furthermore, as these authors pointed out, the emotional appraisal of the subtle structural aspects of music can be immediate. Less than a quarter of a second of music is sufficient to elicit reliable emotional judgments. Extremely fast-acting processes are typically observed in response to biologically important stimuli. The fact that short musical extracts can arouse similar emotional responses in every human being, with rapid onset and with little awareness, qualifies such experiences as reflexes (5).

The study by Zhang et al. (1) has given us the basis to fully explore the changes in monoamine receptors, including dopamine receptor $2\left(\mathrm{D}_{2}\right)$ and 5-hydroxytryptamine receptor $2 \mathrm{~A}$ (5$\mathrm{HT}_{2 \mathrm{~A}}$ ), induced by frightening music. First, ${ }^{11} \mathrm{C}$-NMSP binding significantly decreased bilaterally in the caudate nu- cleus region, indicating that frightening music triggers downregulation of postsynaptic $\mathrm{D}_{2}$. This result, together with results from previous studies, suggested that the caudate nucleus is involved in a wide range of emotional processes evoked by music $(6,7)$. Second, ${ }^{11} \mathrm{C}$ NMSP binding in the right amygdala increased significantly in response to frightening music. The amygdala is considered the most important structure-it receives the information and determines the significance of the stimuli and triggers emotional responses (8). Third, Zhang et al. (1) found increased ${ }^{11} \mathrm{C}$ NMSP binding in the frontal, temporal, and occipital cortices when comparing the baseline condition with the frightening-music condition, indicating that the amygdala receives frightening-music stimuli from the limbic and paralimbic systems and then sends its afferents to the cortex. Within the cortex, the stimuli are analyzed using information from many parts of the brain, and a message is sent back down to the amygdala; in return, the amygdala reacts to stimuli and triggers physiologic responses. The metaanalysis of emotional processing revealed that the amygdala not only is activated during the fear condition in healthy subjects but also is related to the emotional neurocircuit in anxiety disorders, such as posttraumatic stress disorder, social anxiety disorder, and phobias (8). The current study provided further evidence at the receptor level and indicated that frightening music triggers functional regulation of monoamine receptors. These findings will help us to determine the mechanism by which the brain responds to fear and gain a better understanding of anxiety disorders, thus enabling us to develop and implement preventive and treatment interventions for anxiety disorders that will reduce the risk that dis- 
eased will develop or will improve its prognosis once present.

The described PET probe in the study by Zhang et al. (1) has an advantage over the previously reported study using ${ }^{11} \mathrm{C}$-raclopride PET (6), because the binding of ${ }^{11} \mathrm{C}$-raclopride to $\mathrm{D}_{2}$ in the striatum is reversible in the time frame of a PET scan and competitive with that of endogenous dopamine, which could not reflect the actual changes at the postsynaptic receptor level. In contrast, ${ }^{11} \mathrm{C}-\mathrm{NMSP}$, as a $\mathrm{D}_{2}$ and $5-\mathrm{HT}_{2 \mathrm{~A}}$ antagonist, binds the receptors that were substantially irreversible in the time frame of a PET scan and was originally used to detect dopamine receptor densities in the basal ganglia (9). Because ${ }^{11} \mathrm{C}$-NMSP is not competitive with endogenous dopamine $(10,11)$ and serotonin (12), binding of ${ }^{11} \mathrm{C}$-NMSP can directly reflect a postsynaptic monoamine receptor level more accurately than can binding of ${ }^{11} \mathrm{C}$-raclopride. Moreover, because ${ }^{11} \mathrm{C}$-NMSP binds predominantly to $\mathrm{D}_{2}$ in the striatum and to 5$\mathrm{HT}_{2 \mathrm{~A}}$ in the cortex, the antagonist could also be used to map these receptors directly and simultaneously in the same individual $(13,14)$.
The article by Zhang et al. (1) describes the first PET study of postsynaptic monoamine receptor changes in healthy volunteers in response to frightening music. Although the study includes a relatively small number of subjects, it nevertheless introduces an important finding - that is, frightening music triggers rapid changes in brain monoamine receptors. The authors are to be congratulated for bringing these novel findings to our attention, and we look forward to further dialogue on the continuing interesting research in the coming years.

\section{Yasuyoshi Watanabe \\ RIKEN Center for Molecular Imaging \\ Science Kobe, Japan}

\section{REFERENCES}

1. Zhang Y, Chen Q, Du F, et al. Frightening music triggers rapid brain monoamine receptor changes: a pilot PET study. J Nucl Med. 2012;53:1573-1578.

2. Pereira CS, Teixeira J, Figueiredo P, Xavier J, Castro SL, Brattico E. Music and emotions in the brain: familiarity matters. PLOS ONE. 2011;6: e27241.

3. Zatorre RJ. Music and the brain. Ann N Y Acad Sci. 2003;999:4-14.

4. Bigand E, Filipic S, Lalitte P. The time course of emotional responses to music. Ann N Y Acad Sci. 2005;1060:429-437.
5. Peretz I, Gagnon L, Bouchard B. Music and emotion: perceptual determinants, immediacy, and isolation after brain damage. Cognition. 1998;68:111-141.

6. Salimpoor VN, Benovoy M, Larcher K, Dagher A, Zatorre RJ. Anatomically distinct dopamine release during anticipation and experience of peak emotion to music. Nat Neurosci. 2011;14:257-262.

7. Bressan RA, Crippa JA. The role of dopamine in reward and pleasure behavior: review of data from preclinical research. Acta Psychiatr Scand Suppl. 2005;427:14-21.

8. Etkin A, Wager TD. Functional neuroimaging of anxiety: a meta-analysis of emotional processing in PTSD, social anxiety disorder, and specific phobia. Am J Psychiatry. 2007;164:1476-1488.

9. Wagner HN Jr, Burns HD, Dannals RF, et al. Imaging dopamine receptors in the human brain by positron tomography. Science. 1983;221: 1264-1266.

10. Morris ED, Yoder KK. Positron emission tomography displacement sensitivity: predicting binding potential change for positron emission tomography tracers based on their kinetic characteristics. J Cereb Blood Flow Metab. 2007;27: 606-617.

11. Ishibashi $\mathrm{K}$, Ishii $\mathrm{K}$, Oda $\mathrm{K}$, Mizusawa $\mathrm{H}$, Ishiwata $\mathrm{K}$. Competition between ${ }^{11} \mathrm{C}$-raclopride and endogenous dopamine in Parkinson's disease. Nucl Med Commun. 2010;31:159-166.

12. Paterson LM, Tyacke RJ, Nutt DJ, Knudsen GM. Measuring endogenous 5-HT release by emission tomography: promises and pitfalls. J Cereb Blood Flow Metab. 2010;30:1682-1706.

13. Nyberg S, Eriksson B, Oxenstierna G, Halldin C, Farde L. Suggested minimal effective dose of risperidone based on PET-measured D2 and 5-HT2A receptor occupancy in schizophrenic patients. Am J Psychiatry. 1999;156:869-875.

14. Gefvert O, Lundberg T, Wieselgren IM, et al. $\mathrm{D}_{2}$ and $5 \mathrm{HT}_{2 \mathrm{~A}}$ receptor occupancy of different doses of quetiapine in schizophrenia: a PET study. Eur Neuropsychopharmacol. 2001;11:105-110. 